\title{
SOCIO-PSYCHOLOGICAL
}

\section{CHARACTERISTICS OF PATIENTS}

WITH SCHIZOPHRENIA RECEIVING

COMPULSORY INPATIENT AND

OUTPATIENT TREATMENT AND

VOLUNTARY PSYCHIATRIC PATIENTS

\author{
Sergii Boltivets \\ Grigory Kostyuk Psychological Institute of the Ukrainian \\ National Academy of Pedagogical Sciences, Ukraine \\ Email: boltivetssergij@i.ua
}

Yuliya Chelyadyn, Tymur Gonchar, Lyudmila Uralova, Oleksandr Bashinskii

Shupyk National Medical Academy of Postgraduate Education, Ukraine

Email: chelyadyn.yuliya@gmail.com,gonchar@nmapo.edu.ua, uralova.lyudmila@gmail.com

\begin{abstract}
The aim of the research was to obtain data for scientific justification and development of an algorithm of medico-social rehabilitation for patients with schizophrenia under compulsory out-and inpatient treatment. During the research clinical and social-demographic conditions were evaluated for the chosen group of people currently undergoing coercive treatment and for the control group. The role of the clinicalpsychopathological and social-environmental agents that caused patients compulsory hospitalization was determined. The level of social functioning and the dissocializing factors were evaluated.
\end{abstract}

Keywords: schizophrenia, coercive treatment, social-psychological characteristics.

\section{Introduction}

Study of the mechanisms of pathogenesis of mental disorders, discovery of their differential diagnostic markers, development of new therapeutic models to increase the period of remission and to eliminate the consequences of social disability are leading areas of modern psychiatry (Bacherikov \& Mudrenko, 2007; Bitensky, 2007; Dobrohotova et al., 2000; Dobrohotova, 2006). The priority of evidence-based medicine dictates the importance of research problems, whose solution will contribute to a significant improvement in the quality of diagnosis, treatment, and prevention of mental illness (Yurieva, 2010; Maruta, 2011; Tabachnikov, Ignatov, \& Markova, 2002).

Schizophrenia remains one of the central problems in psychiatry over a long period of time; its significance is caused not only by the high incidence of the disease among the general population but also by social disadaptation, disability and involuntary psychiatric care for such patients. 
The problem of deciding the necessity of compulsory psychiatric care for persons with mental disorders, organization and implementation of such an event are the most difficult and responsible tasks for specialists both in general and forensic psychiatric practice (Nagnibida \& Nitrutsa, 2000; Nasinnik, 2007, 2009).

This is due, first of all, to the nature of mental disorders, some of which may be a threat to both the carrier and those around him. Second, the natural need to coerce the mentally ill carries the risk of violating his rights and promotes the temptation to intentionally use violence to achieve a specific goal.

An introduction of the new legislation in psychiatry, first of all, of the Law of Ukraine "On Psychiatric Care", introduces new approaches also in providing such assistance, particularly in providing compulsory treatment. New special research and development of scientifically sound recommendations are required (Kuznetsov, 2009; Nasinnik, 2008).

The lack of a program of medico-social rehabilitation that accounts for the structure of psychopathological symptoms in schizophrenia, for the quality of life and social functioning of patients in the course of compulsory psychiatric treatment, significantly limits the scope of medical possibilities in modern clinical practice.

All said above emphasizes the relevance and feasibility of the study of the whole spectrum of clinical and psychopathological, socio-psychological mechanisms leading to compulsory treatment, of the criteria to select and control psychiatric rehabilitation measures. Thus, the purpose of the study was to determine the socio-psychological features of people suffering from schizophrenia to develop an algorithm for medico-social rehabilitation of this type of patients.

\section{Research Methodology}

\section{General Background}

The purpose of the work was to develop an algorithm for the introduction of differentiated, pathogen-oriented medical and social rehabilitation taking into account the clinical, psychopathological and socio-psychological features of patients with schizophrenia in the process of providing inpatient and outpatient psychiatric care in compulsory order.

To implement the stated purpose, the following tasks were defined:

1. To determine the level of social functioning in the groups of patients under study.

2. To establish provoking clinical-psychopathological and socio-psychological factors that cause compulsory treatment of patients with schizophrenia.

The subject of the research was compulsory psychiatric care for patients with schizophrenia.

The targets were clinical-psychopathological specifics in patients with paranoid form of schizophrenia receiving compulsory psychiatric care, medical and social rehabilitation of patients with schizophrenia during the provision of compulsory medical care at the inpatient and outpatient stages.

\section{Methods}

The research was conducted with the help of the following methods: clinical-anamnestic, clinical-psychopathological, psycho-diagnostic, socio-demographic, statistical.

The clinical-anamnestic method included the study of the anamnesis and the history of the disease, hereditary burden of mental pathology, especially the debut of mental disorders; dynamics of the clinical picture for the whole period of the disease; quality and specifics of remission periods; presence and specifics of personality changes; the volume and nature of psychiatric care received, the effectiveness of the treatment performed.

Clinical-psychopathological method was used to determine the main psychopathological disorders, symptomatic manifestations and syndromic structure thereof, as well as their dynamics in the course of medico-social rehabilitation in the contingent of patients under study. 
The WHODAS 2.0 schedule (World Health Organization, 2018) was used to examine the level of social functioning: social exclusion, self-care, involvement in household chores, sexual role, interpersonal communication, performance and interest in the work done, return to learning, interest and awareness.

The psycho-diagnostic method was used to identify negative and positive symptoms according to the PANSS scale (Positive and Negative Syndrome Scale) (Allen \& Becker, 2019). The Hamilton Depression and Anxiety Scale (Hamilton, 1959, 1960) was used to determine depression and anxiety in the study groups.

The processing of digital data was performed by different mathematical means, the choice of which was determined by the task in each case. The calculations were performed on a personal computer using Statistica 6.0 application package. The difference was considered significant at $p<.05$. The employed methods were - descriptive statistics, Student t-criterion, Fisher criterion, correlation and multifactor analysis.

\section{Research Group}

The study included 155 patients with paranoid schizophrenia under the condition of informed consent following the principles of bioethics and deontology; they were distributed between the main group and the comparison group. The main group consisted of 80 subjects, 51 men and 29 women aged 20 to 55 and more; the members of the group received compulsory treatment.

The comparison group consisted of 75 patients, 32 men and 43 women whose age was in the same range as in the main group; the patients in the group applied for psychiatric help voluntarily.

The diagnosis was established according to the World Health Organization (2010).

\section{Research Results}

A comparative analysis of positive, negative and general psychopathological symptoms was carried out using the PANSS scale; the results are shown in the table. As can be seen from Table 1, the superiority of the main group over the control one in terms of severity of positive syndromes is statistically significant. Dominant here are delusion $(5.26 \pm 0.18$ points in the main group versus $2.92 \pm 0.15$ points in the comparison group, $p<.05$ ), thinking disorders (5.40 \pm 0.14 points in the main group versus $3.71 \pm 0.13$ points in the comparison group, $p<.05$ ), agitation ( $5.65 \pm 0.14$ points in the main group versus $2.02 \pm 0.11$ points in the comparison group, $p$ $<.05)$, hostility ( $5.00 \pm 0.10$ points in the main group versus $2.22 \pm 0.08$ points in the comparison group, $p<.05$ ), suspiciousness $(4.35 \pm 0.19$ points in the main group versus $2.55 \pm 0.16$ points in the comparison group, $p<.05)$.

Negative symptoms are also more pronounced in patients in the main group than in people in the comparison group. They are manifested in stereotypical thinking $(4.64 \pm 0.12$ against $2.60 \pm 0.07$ pts., $p<.05)$, in spontaneity of speech impairment $(4.60 \pm 0.12$ against $3.88 \pm 0.10$ pts., $p<.05)$, in social detachment $(4.49 \pm 0.16$ against $3.75 \pm 0.14, p<.05)$, in emotional detachment (3.53 \pm 0.18 against $2.40 \pm 0.11$ ), in communication difficulties $(4.11 \pm 0.14$ against $2.59 \pm 0.08)$. The expression of general psychopathological syndromes in the main group prevailed over that in the comparison group. The most loaded symptoms are the psyche overload by anxiety $(5.60 \pm 0.09$ against $3.05 \pm 0.07, p<.05)$, unusual content of thoughts $(5.26 \pm 0.14$ against $3.04 \pm 0.03, p<.05)$, decreased criticality $(6.23 \pm 0.08$ against $3.32 \pm 0.07, p<.05)$, active social detachment $(5.68 \pm 0.11$ against $2.89 \pm 0.06, p<.05)$, volition disorder $(5.51 \pm 0.07$ against $3.44 \pm 0.06, p<.05)$.

Comparative analysis of the positive, negative, and general psychopathological symptoms of the PANSS scale confirmed the presence of cognitive impairment in both study groups. Statistically significant differences between the groups were obtained in the decreased criticality 
78 in awareness of the disease (average score in the main group was $6.23 \pm 0.08$ against $3.32 \pm 0.07$ in the comparison group, $p<.05)$, in disorganization of thought $(5.40 \pm 0,14$ against $3.71 \pm 0.13$, $p<.05)$, attention $(5.56 \pm 0.12$ against $3.35 \pm 0,1, p<.05)$, volition $(5.51 \pm 0.07$ against $3.35 \pm 0.10$, $p<.05)$, active social detachment (5.68 \pm 0.11 against $2.89 \pm 0.06, p<.05)$.

Table 1. PANSS scores for the main and comparison groups.

\begin{tabular}{|c|c|c|}
\hline Symptoms & Main group $(n=80)$ & $\begin{array}{c}\text { Comparison group } \\
\qquad(n=75)\end{array}$ \\
\hline \multicolumn{3}{|c|}{ Positive symptoms } \\
\hline Delusion & $5.26 \pm 0.18$ & $2.92 \pm 0.15$ \\
\hline Thinking disorders & $5.40 \pm 0,14$ & $(3.71 \pm 0.13)^{*}$ \\
\hline Hallucinations & $4.03 \pm 0.22$ & $2.68 \pm 0.27$ \\
\hline Agitation & $5.65 \pm 0.14$ & $(2.02 \pm 0.11)^{*}$ \\
\hline Ideas of greatness & $3.95 \pm 0.21$ & $(2.18 \pm 0.17)^{*}$ \\
\hline Suspiciousness, ideas of persecution & $4.35 \pm 0.19$ & $2.55 \pm 0.16$ \\
\hline Hostility & $5.00 \pm 0.16$ & $2.22 \pm 0.08$ \\
\hline \multicolumn{3}{|c|}{ Negative symptoms } \\
\hline Blunted affect & $3.99 \pm 0.16$ & $(2.95 \pm 0.16)^{*}$ \\
\hline Emotional detachment & $3.53 \pm 0.18$ & $2.40 \pm 0.11$ \\
\hline Social detachment & $4.49 \pm 0.16$ & $(3.75 \pm 0.14)^{*}$ \\
\hline Communication difficulties & $4.11 \pm 0.14$ & $2.59 \pm 0,08$ \\
\hline Abstract thinking violations & $4.31 \pm 0.11$ & $3.67 \pm 0.10$ \\
\hline Spontaneity of speech impairment & $4.60 \pm 0.12$ & $(3.88 \pm 0.10)^{*}$ \\
\hline Stereotypical thinking & $4.64 \pm 0.12$ & $(2.60 \pm 0.07)^{*}$ \\
\hline \multicolumn{3}{|c|}{ General psychopathological symptoms } \\
\hline Somatic concerns & $3.21 \pm 0.18$ & $2.91 \pm 0.13$ \\
\hline Anxiety & $2.86 \pm 0.19$ & $(3.96 \pm 0,13)^{*}$ \\
\hline Guilt & $3.51 \pm 0.21$ & $2.87 \pm 0.14$ \\
\hline Tenseness & $4.46 \pm 0.17$ & $(3.52 \pm 0.12)^{*}$ \\
\hline Mannerism and posing & $4.10 \pm 0.16$ & $(2.72 \pm 0.12)^{*}$ \\
\hline Depression & $2.73 \pm 0.16$ & $(3,85 \pm 0,11)^{*}$ \\
\hline Motoric retardation & $3.10 \pm 0.14$ & $2.49 \pm 0.10$ \\
\hline Low contact ability & $4.38 \pm 0.13$ & $(3.03 \pm 0.12)^{*}$ \\
\hline Unusual content of thoughts & $5.26 \pm 0.14$ & $(3.04 \pm 0.03)^{*}$ \\
\hline Disorientation & $4.86 \pm 0.15$ & $(2.55 \pm 0.10)^{*}$ \\
\hline Attention impairment & $5.56 \pm 0.12$ & $(3.35 \pm 0.10)^{\star}$ \\
\hline Decreased criticality & $6.23 \pm 0.08$ & $(3.32 \pm 0.07)^{*}$ \\
\hline Volition disorder & $5.51 \pm 0.07$ & $(3.44 \pm 0.06)^{*}$ \\
\hline Aggressiveness & $5.03 \pm 0.11$ & $(2.60 \pm 0.07)^{*}$ \\
\hline Psyche overload by anxiety & $5.60 \pm 0.09$ & $(3.05 \pm 0.07)^{*}$ \\
\hline Active social detachment & $5.68 \pm 0.11$ & $(2.89 \pm 0.06)^{*}$ \\
\hline
\end{tabular}

* Difference between the main and comparison groups is statistically significant $(p<.05)$

Comparative analysis of the positive, negative, and general psychopathological symptoms of the PANSS scale confirmed the presence of cognitive impairment in both study groups. Statistically significant differences between the groups were obtained in the decreased criticality 
in awareness of the disease (average score in the main group was $6.23 \pm 0.08$ against $3.32 \pm 0.07$ in the comparison group, $p<.05)$, in disorganization of thought $(5.40 \pm 0,14$ against $3.71 \pm 0.13$, Vol. 13, No. 2, 2019 $p<.05)$, attention $(5.56 \pm 0.12$ against $3.35 \pm 0,1, p<.05)$, volition $(5.51 \pm 0.07$ against $3.35 \pm 0.10$, $p<.05)$, active social detachment $(5.68 \pm 0.11$ against $2.89 \pm 0.06, p<.05)$.

The analysis of the presented data demonstrates a wide range of disorders of cognitive activity: from the activation-energetic disorders to the operative-regulatory ones, with the considerable advantage thereof in the patients of the first group. The clarity of manifestation and expression of these symptoms implies a violation of the purpose statement and control of mental activity, which is naturally reflected by the social adaptation of the research subjects.

Among positive symptoms taken into account by the PANSS scale that described behaviors not due to external stimuli the most pronounced in the patients of the main group, unlike those of the comparison group, were delusions (average score $5.26 \pm 0.18$ against $2.92 \pm 0.15$ ), hallucinations ( $4.03 \pm 0.22$ against $2.68 \pm 0.27$ ), suspicion, ideas of persecution ( $4.35 \pm 0.19$ against $2,55 \pm 0.16$ ).

Among negative symptoms of the scale that characterize behavior disorders and reflect relation of the subject to other people - from emotional sensitivity to the verbal-communicational processes the patients in both groups showed social detachment (average score for the main group patients $-4.49 \pm 0.16$, correspondingly for the comparison group - $3.75 \pm 0.14, p<.05$ ), communication difficulties $(4.11 \pm 0.14$ against $2.59 \pm 0,08)$, spontaneous speech impairment (4.60 \pm 0.12 against $3.88 \pm 0.10, p<.05)$.

Among general psychopathological symptoms of the scale causing violations of behavior the most expressed in both groups were aggressiveness (average score in the main group was $5.03 \pm 0.11$ against $2.60 \pm 0.07$ for the comparison patients, $p<.05$ ) and unusual thought content (5.26 \pm 0.14 against $3.04 \pm 0.03, p<.05)$.

Depression and anxiety were determined for the last seven- day periods with the help of the Hamilton scale; the process was based on the clinical interview moving from the questions about general symptoms to more specific ones that allowed to estimate severity thereof. We used information obtained from the patient himself, from his relatives and from the medical staff. The data were then evaluated according to the points assigned.

The results of the research of depression and anxiety levels in the group of patients who received compulsory psychiatric treatment and in the group of those who applied for help voluntarily are shown in Table 2.

Table 2. Hamilton average scores for main and control group subject's anxiety at hospital admission.

\begin{tabular}{ccc}
\hline Indicator & Main group $(n=80)$ & Comparison group $(n=75)$ \\
\hline Mental anxiety & $1.20 \pm 0.04$ & $(2.03 \pm 0.06)^{*}$ \\
Somatic anxiety & $0.59 \pm 0.01$ & $(1.28 \pm 0.03)^{*}$ \\
\hline
\end{tabular}

* Difference between the main and comparison groups is statistically significant $(p<.05)$

The results of the investigation with the help of the Hamilton Depression Scale are presented in Table 3.

Table 3. Comparative rates of depression in the main and comparison groups, abs. value(\%).

\begin{tabular}{lccc}
\hline Indicator expression degree & Points & Main group $(\mathrm{n}=\mathbf{8 0})$ & Comparison group $(\mathrm{n}=\mathbf{7 5})$ \\
\hline No depressive episode & $0-6$ & $58(72.50)$ & $32(42.70)$ \\
Easy depressive episode & $7-16$ & $1(1.25)$ & $2(2.70)$ \\
Moderate depressive episode & $17-27$ & $9(11.25)$ & $15(20.00)$ \\
Major depressive episode & $>27$ & $12(15.00)$ & $26(34.60)$ \\
\hline
\end{tabular}


The data in Table 3 show the prevalence of the depressive episodes in particular of moderate and major ones in patients who applied for the psychiatric help voluntarily in comparison to the patient who received compulsory treatment. The data obtained are important in identifying patients with persistent suicidal ideation and self-inflicted injury and enable the development of an algorithm for medico-social rehabilitation of the said contingent of patients.

In order to determine social eligibility, we studied the levels of social functioning for the patients with schizophrenia both for those under compulsory treatment and those who applied for help voluntarily.

Social functioning level results obtained according to the WHODAS 2.0 scale are presented in Table 4.

The data demonstrate that the main group of patients has a tendency for self-isolation. During the last months before hospitalization they maintained extremely limited level of social contacts, actively avoided being in the presence of other people, locked themselves in their room or left their houses (average score for the main group was $4.50 \pm 0.12, p<.05$ ). The patients from the comparison group also showed some social detachment and exclusion $(2.69 \pm 0.06$, $p<.05)$ but we were unable to see a significant tendency for self-isolation.

Table 4. Indicators of the level of social functioning in patients of the main group and comparison groups.

\begin{tabular}{lcc}
\hline \multicolumn{1}{c}{ Indicator } & Main group $(n=80)$ & Comparison group $(n=75)$ \\
\hline Social detachment & $4.5 \pm 0.12$ & $(2.69 \pm 0.06)^{*}$ \\
Self-care & $3.74 \pm 0.08$ & $(1.96 \pm 0.04)^{*}$ \\
Housekeeping participation & $4.49 \pm 0.06$ & $(2.91 \pm 0.05)^{*}$ \\
Sexual role & $4.29 \pm 0.11$ & $(1.53 \pm 0.06)^{*}$ \\
Difficulty in personal relations & $4.15 \pm 0.10$ & $(3.12 \pm 0.04)^{*}$ \\
$\begin{array}{l}\text { Work performance } \\
\text { Interest in getting a job or returning to work, } \\
\text { studying }\end{array}$ & $4.45 \pm 0.06$ & $(2.52 \pm 0.07)^{*}$ \\
$\begin{array}{l}\text { Degree of interest and command of } \\
\text { information }\end{array}$ & $4.54 \pm 0.06$ & $(3.11 \pm 0.04)^{*}$ \\
\hline
\end{tabular}

${ }^{*}$ Difference between the main and comparison groups is statistically significant $(p<.05)$

In the main group, self-care was largely insufficient: patients were negligent, looked like vagrants or neglected personal hygiene, dirty, ragged, exhausted (average score was $3.74 \pm 0.08$, $p<.05)$. At the same time, the patients in the comparison group only to a certain degree lost interest in their appearance: their closes were sloppy, showed lack of tidiness but were not completely ragged (the score was $1.96 \pm 0.04, p<.05$ ).

Home-based activities for patients in the main group boiled down either to implement decisions made by other family members, to stay away from home affairs, or to completely exclude themselves from household co-operation $(4.49 \pm 0.06, p<.05)$. At the same time, the comparison group was characterized by less-than-expected participation in the household, reduced interest in household chores, narrowing of the functions in this field, and a certain inability $(2.91 \pm 0.05, p<.05)$.

While studying the sexual roles of the patients it was discovered that in relations with other people those from the main group had no sexual interest in anybody, showed zero reaction to sexual stimuli and hostility towards opposite sex; in some cases, disordered sexual relations took place $(4.29 \pm 0.11, p<.05)$. In the comparison group, the patients showed some sexual interest or had relations but without establishing more permanent connections even in spite of having such an opportunity. There was an obvious decrease in sexual interest, or, even if such 
interest was present, there was no attempt to approach another person $(1.53 \pm 0.06, p<.05)$. Complications in personal relationships in the subjects of the main group main manifested Vol. 13, No. 2, 2019 itself in suspicion, hostility.

It's worth mentioning that employed patients from the main group were absent from work most of the time during the month, quality of the completed work significantly decreased, there were administrative sanctions $(4.45 \pm 0.06, p<.05)$. The professional role of the subjects from the comparison group reduced to complains that the job was hard, the quality of the completed work and its productivity decreased partially $(2.52 \pm 0.07, p<.05)$. It should be noted that in the main group able-bodied patients who did not work and did not study, showed complete indifference and resisted opportunities to get a job or continue training $(4.54 \pm 0.06, p<.05)$. The comparison group characteristic was low interest in finding a job or continuing training, lack of initiative and passive submission $(3.11 \pm 0.04, p<.05)$. In the main group typical is the complete absence of interest to local and international events. At the same time, the subjects of the comparison group showed reduced interest in the world events, made no efforts to receive news from media (subsequent scores were $4.59 \pm 0.06$ against $2.49 \pm 0.06, p<.05)$. The differences were statistically significant. The data presented demonstrated a significant decrease in the level of social functioning in patients with schizophrenia who underwent compulsory treatment.

\section{Discussion}

Thus, it was found in the research that the leading role in both groups played hallucinatoryparanoid and paranoid syndromes; less frequently patients in the groups had psychopathic, depressive-paranoid, anxiety-depressive and manioform syndromes, moreover psychopathic and manioform syndromes statistically significantly prevailed in the group of patients with schizophrenia who received compulsory psychiatric help. It was established that the clinical picture of psychopathological disorders in patients of the main group was dominated by expressive verbal pseudo-hallucinations with imperative content, delusional ideas of grandeur, persecution, influence, accompanied by behavior disorders, leading to maladaptation in society. At the same time, in patients of the comparison group, the main psychopathological symptoms were combined with reduced affect, anxiety symptoms, and psychopathological manifestations. According to the Hamilton scale of depression and anxiety, it was found that in the group of patients who sought psychiatric help voluntarily, in most cases there were moderate and severe depressive episodes. The indicators of the level of mental and somatic anxiety in the patients of the comparative group also statistically significantly outweighed the same indicators in the main group subjects. Analogous results were obtained in several studies conducted for different countries (Cocchi et al., 2014; Miret et al., 2016; Tenório, 2016).

It has been established that the mechanisms of the formation of behavioral disorders in patients with schizophrenia receiving compulsory psychiatric care were in most cases productive-psychotic, and to a lesser extent, negative-personal. In most cases, the subjects of the main group showed aggression towards their relatives. In the majority of cases, verbal aggression was accompanied by physical aggression.

Based on the analysis of the PANSS scores for the positive symptoms reflecting behaviors not caused and confirmed by external stimuli, we could conclude that the most pronounced in the main group patients unlike the comparison group ones were symptoms of delusions, hallucinations, suspiciousness, and persecution ideas.

Among negative symptoms that characterize behavior disorders and reflect the state of relations with other people in the range from emotional sensitivity up to verbal-communicative processes, the subjects of both groups showed symptoms of social detachment, emotional detachment, communication difficulties, and spontaneity of speech impairment.

The comparative analysis of positive, negative and general psychopathological symptoms of the PANSS scale confirmed that the patients in both groups had cognitive disorders. We obtained statistically significant differences between people in both groups in the symptoms 
of decreased criticality in awareness of the disease; disorganization of thinking; violations of abstract thinking, attention, volition; active social detachment.

\section{Conclusions}

The analysis of the presented data demonstrates a wide range of disorders of cognitive activity: from activation-energy disorders to operative-regulatory ones with much higher incidence rates for patients in the main group.

According to the results of the research, it was proved that compared to patients who applied for psychiatric help voluntarily, the patients receiving it under compulsory procedure had a significantly reduced level of social functioning.

Thus, summarizing the results of the study, it can be argued that the combined effect of psychopathological manifestations of the leading syndrome in the main group (verbal pseudohallucinations with imperative content, delusional ideas of persecution and influence, behavioral disorders) and of evident cognitive degradation is the cause of the sharp social adaptation ability reduction and possibly is a syndrome-forming factor of involuntary treatment.

\section{References}

Allen, D. N., \& Becker, M. L. (2019). Diagnostic and Symptoms interview for adults. In Gerald Goldstein, Daniel L. Allen \& John DeLuca (Eds.), Handbook of psychological assessment (pp. 356-393). NY: Academic Press.

Bacherikov, A. N., \& Mudrenko, I. G. (2007). Osobennosti pokazatelya kachestva jizni u bolnih s autoagressivnym poviedeniem vo vremya pervogo epizoda shizofrenii [Features of the quality of life indicator in patients with auto-aggressive behavior during the first episode of schizophrenia]. Журнал психиатрии и медииинской психологии, 1(17), 26-31.

Bitensky, B. C. (2007). Kliniko-patogenichni aspekty alkogolizmu I narkomanii [Clinical and pathogenic aspects of alcoholism and drug addiction]. Вісник психотерапії та психофармакотерапіï, 11, 7-11.

Cocchi, A., Cerati, G., Lora, A., Meneghelli, A., Monzani, E., Percudani, M., Petrovich, L., Mirabella, F., Picardi, A., \& Preti, A. (2014). Patients with first-episode psychosis are not a homogeneous population: Implications for treatment. Clinical Practice and Epidemiology in Mental Health, 10, 1-8. https:// dx.doi.org/10.2174\%2F1745017901410010001.

Dobrohotova, T. A., Bragina, N. N., Zaitsev, O. S., Urakov, S. B., \& Fisenko I. N. (2000). Neiropsichiatriya I psychiatriya na sovremennom etape razvitiya medicinskih nauk [Neuropsychiatry and psychiatry at the present stage of development of medical sciences]. Социальная и клиническая психиатрия, 1, 88-91.

Dobrohotova, Т. А. (2006). Neiropsichiatriya. Москва: БИНОМ.

Hamilton, M. (1959). The assessment of anxiety states by rating. British Journal of Medical Psychology, 32(1), 50-55. https://doi.org/10.1111/j.2044-8341.1959.tb00467.x.

Hamilton, M. (1960). A rating scale for depression. Journal of Neurology, Neurosurgery, and Psychiatry, 23(56-62), 28-29.

Kuznetsov, V. N. (2009). Urgentnaya pomohsch v psychiatrii [Urgent help in psychiatry]. Психічне здоров'я, 3-4(24-25), 71-80.

Maruta, N. O. (2011). Stan nadannya ta perspektivy rozvytku psychiatrychoi dopomogi v Ukraini [State of provision and prospects of psychiatric care in Ukraine]. Apxis ncuxiampiï, 3(66), 5-8.

Miret, S., Fatjó-Vilas, M., Peralta, V., Fañaná, L. (2016). Basic symptoms in schizophrenia, their clinical study and relevance in research. Revista de Psiquiatria y Salud Mental, 9(2), 111-122.

Nagnibida, A. N., \& Nitrutsa, M. I. (2000). Skoraya psychiatricheskaya pomoshch na dogospitalnom etape [Emergency psychiatric care at the prehospital stage]. СПб: СпецЛит.

Nasinnik, O.A. (2007). Otsenka algoritma, etapov, preemstvennosti psihiatricheskoy pomoshchi v prinuditelnom poryadke: sootvetstvie zakonodatelstvu [Assessment of the algorithm, stages, succession of compulsory psychiatric care]. Психічне здоров'я, 4(17), 87-93. 
Nasinnik, O. A. (2008). Chastota nedobrovolnyh hospitalizatsii I kliniko-sotzialnye harakteristiki patsientov do I posle prinyatiya Zakona Ukrainu "O psihiatrycheskoy pomoshchi” [The frequency of involuntary hospital admissions and the clinical and social characteristics of patients before and after the adoption of the Law of Ukraine "On Psychiatric Care"]. Психічне здоровя, 3-4(20-21), 116-123.

Nasinnik, O. A. (2009). Formirovanie criteriev prinuditelnogo uderzhivanya lits s psihiatricheskimi rasstroystvami [Formation of criteria for the compulsory retention of persons with psychiatric disorders]. Психічне здоровя, 3-4(20-21), 24-25.

Tabachnikov, S. I., Ignatov, M. Yu., \& Markova, M. V. (2002). Psyhychne zdorov'ya naselennya Ukrainy z tochki zoru fahivtsiv sotsialnoyi psyhiatrii [Mental health of the population of Ukraine from the point of view of social psychiatry specialists]. Охорона Здоров'я України, 4(1), 11-17.

Tenório, F. (2016). Psychosis and schizophrenia: Effects of changes in psychiatric classifications on clinical and theoretical approaches to mental illness. História, Ciências, Saúde-Manguinhos, 23(4), 941-963. https:// doi.org/10.1590/S0104-59702016005000018.

World Health Organization. (2010). International classification of diseases for mortality and morbidity statistics. Retrieved from https://icd.who.int/browse10/2010/en.

World Health Organization. (2018) WHO Disability assessment schedule 2.0. Retrieved from https://www. who.int/classifications/icf/more_whodas/en.

Yurieva, L. N. (2010). Shizofreniya. Klinicheskoye rukovodstvo dlya vrachei [Schizophrenia. Clinical Guide for Physicians]. Киев: Новая Идеология.

Received: September 30, 2019

Accepted: December 02, 2019

\begin{tabular}{|c|c|}
\hline Sergii Boltivets & $\begin{array}{l}\text { Doctor of Psychological Sciences, Professor, Head of the Department of Youth } \\
\text { Policy Development, State Institute of Family and Youth Policy of Ukraine, } \\
\text { Ukraine. } \\
\text { E-mail: boltivetssergij@i.ua }\end{array}$ \\
\hline Yuliya Chelyadyn & $\begin{array}{l}\text { Candidate of Medical Sciences, Assistant Professor, Department of Psychiatry, } \\
\text { Psychotherapy and Medical Psychology, Shupyk National Medical Academy of } \\
\text { Postgraduate Education, Ukraine. } \\
\text { E-mail: chelyadyn.yuliya@gmail.com }\end{array}$ \\
\hline Tymur Gonchar & $\begin{array}{l}\text { Candidate of Medical Sciences, Associate Professor, Department of Psychiatry, } \\
\text { Psychotherapy and Medical Psychology, Shupyk National Medical Academy of } \\
\text { Postgraduate Education, Ukraine. } \\
\text { E-mail: gonchar@nmapo.edu.ua }\end{array}$ \\
\hline Lyudmila Uralova & $\begin{array}{l}\text { Candidate of Medical Sciences, Associate Professor, Department of Psychiatry, } \\
\text { Psychotherapy and Medical Psychology, Shupyk National Medical Academy of } \\
\text { Postgraduate Education, Ukraine. } \\
\text { E-mail: uralova.lyudmila@gmail.com }\end{array}$ \\
\hline Oleksandr Bashinskii & $\begin{array}{l}\text { Postgraduate Student of the Department of Psychiatry, } \\
\text { Psychotherapy and Medical Psychology, Shupyk National Medical Academy of } \\
\text { Postgraduate Education, Ukraine. } \\
\text { E-mail: bashynskyioleksandr@gmail.com }\end{array}$ \\
\hline
\end{tabular}

